\title{
Exergy Analysis of Modified Solar Still
}

\author{
Abdul Hadi N. Khalifa* \\ Engineering Technical College, Middle Technical University, Baghdad, Iraq
}

\begin{abstract}
A new design of solar still consist of flat plate solar collector, heat exchanger and cooling tower, was built and tested under Iraq weather at March. The still was tested under different mass flow rate of brackish water entering the flate plate solar collector, ranging from 0.01 to $0.015 \mathrm{~kg} / \mathrm{s}$. The volume flow rate of air through cooling tower was $0.0195 \mathrm{~m}^{3} / \mathrm{s}$. A full details of overall system as well as for system components exergy analysis were achieved. It was found that the maximum daily exergy efficiency of the still is less than $1 \%$. While the maximum hourly exergy efficiency and maximum productivity for such combination were $3.46 \mathrm{~kg}$ /day and $1.6 \%$, respectively, when the mass flow rate of brackish water was $0.013 \mathrm{~kg} / \mathrm{s}$.
\end{abstract}

Keywords: Solar still, exergy analysis, solar collector, cooling tower

\section{Introduction}

Safe water for domestic use is scare today, the World Health Organization [1] estimated that there are more than 750 million around the world facing a problems in getting safe water . In Arab Region, where the growth in population is about $3 \%$ per year [2], the growing demand of safe water exceeding the conventional water resources. In order to cover the gap between the conventional source and water demand a new technologies should be used. One of these technologies is seawater desalination. Al Barwani and Purnama [3] said that the Arabian Gulf is the main source for desalinated seawater to make up deficiencies in the supplies of potable water. They use of solar stills were taken an iIntense interesting around the word. The effect of condensing cover material on the productivity of single basin solar still was studied by Dimri, et al. [4] .They used a single basin single slope solar still with glass and acrylic sheet of $5 \mathrm{~mm}$ thickness as a condensing area. An energy and exergy efficiency were recorded as $36.43 \%$ and $2.73 \%$ for glass cover, while $16.84 \%$ and $1.52 \%$ were record for acrylic sheet. The effect cooling tower on the distillate fresh water was introduced by Marmouch \& Nasrallah [5], they used the humidification-dehumidification desalination process to utilize sustainable energy sources like solar and geothermal energies. A capillary still was introduced by Bhattacharyya.[6] in which a high productivity of distillated water can be

* Corresponding author.

E-mail: ahaddi58@yahoo.com

(C) 2015 International Association for Sharing Knowledge and Sustainability

DOI: $10.5383 /$ ijtee. 10.02 .009 obtained with minimum areas of land and even in cloudy days. Thermal efficiency and exergy analysis for evaluating the thermal performance of double slope active solar still under forced circulation mode were carried by Sethi and Dwivedi [7]. They showed that the daily thermal efficiency of solar still varies from 13.55 to $31.07 \%$ and the exergy efficiency varies from 0.26 to $1.34 \%$. A comprehensive thermodynamic model for exergy analysis of a passive solar distillation system was presented by Ranjan, Kaushik \& Panwar.[8] under climatic conditions of India. They found that the energy and exergy efficiency of the solar still were 30.42 and $4.93 \%$, respectively. Exergy destruction in the process of each component were calculated also. The performance of active single slope solar still using different operational parameters was studied theoretically by Badran [9] . the results were compared with the experimental data for validation purposes, to find out best factors enhancing still productivity. They conclude that active solar stills can be one of the options for enhancing the productivity of still. Balabel, , and Hamdy [10] presented a new imaging of a stand-alone unit for the simultaneously production of fresh water and hydrogen gas from sea water and brackish water.

In this work a combination between flat plate solar collector, heat exchanger and cooling tower was used to produce a distillated water from brackish water. An overall exergy analysis for all system combination were obtained. 


\section{Theoretical work}

\subsection{System description}

A flat plate solar collector of $1.94 \mathrm{~m}^{2}$ net area, heat exchanger, centrifugal fan and cooling tower of cross sectional area of (35 $\mathrm{cm} \times 35 \mathrm{~cm}$ ) and $100 \mathrm{~cm}$ in height, were connected together, to form what is known as a solar still with cooling tower and flat plate solar collector, as shown in Fig.1. The desalination process started when the brackish water at point 1 enters the heat exchanger. This water is used to cool the humid air, leaving cooling tower, below dew point, and, hence condensate the vapour borne with the humid air. The preheated brackish water leaving heat exchanger at point 2 entering the flat plate solar collector. High temperature water leaving solar collector at point 3 entering cooling tower to evaporates there. The evaporation process is achieved by blowing air from bottom of cooling tower at point 5 . The mixture of water vapour and air leaving cooling tower at point 6 , which is known as humid air, is drawn from the top of cooling tower with the aid of a centrifugal fan. Then the humid air entering heat exchanger and an amount of water vapour is extracted there, the leaving air at point 5 which is not humid enough is send back to the cooling tower. The high salinity water leaving tower at point 4 is bleeding outside. The still is tested under different flow rate brackish, ranging from 0.01 to $0.15 \mathrm{~kg} / \mathrm{s}$, with constant volume flow rate of air through cooling tower of $0.0195 \mathrm{~m}^{3} / \mathrm{s}$.

\subsection{Theoretical analysis}

Exergy analysis of system components can summarized as below:

\subsubsection{Solar collector}

In solar intensity (I) falls on glass cover of the collector, as it transmitted through the glass cover a portion of solar radiation equals to (I. $\tau \alpha . \mathrm{A})$ is reached the absorber plat of collector. thus the energy balance of collector is;

I. $\tau \alpha \cdot A=\dot{m}_{n} \cdot c_{n} \cdot\left(T_{3}-T_{2}\right)$

The value of $\tau \alpha$ : transmittance absorptance product, approximately equals 0.88 for single common glass [11].

The exergy of water entering solar collector is:

$\psi_{2}=\left(h_{2}-h_{o}\right)-T_{o} \cdot\left(s_{2}-s_{o}\right)$

While the exergy flow due to mass flow rate of water leaving collector is:

$\psi_{3}=\left(h_{3}-h_{o}\right)-T_{o} \cdot\left(s_{3}-s_{o}\right)$

The absorbed solar radiation exergy rate, assuming the sun as an infinite thermal source [12] is:

$\Psi_{\text {solar }}=$ I. $\tau \alpha \cdot A \cdot\left(1-\frac{T_{o}}{T_{s}}\right)$

Where $T_{s}$ is apparent sun temperature which is about $75 \%$ of the blackbody temperature of the sun, the blackbody temperature of the sun is assumed to be $4500 \mathrm{~K}$ [12]

The exergy efficiency of solar collector equals to [11]:

$\eta_{\text {coll. }}=\frac{\dot{\mathrm{m}}_{\mathrm{w}} \cdot\left(\Psi_{3}-\Psi_{2}\right)}{\Psi_{\text {heat }}}$

\subsubsection{Cooling tower}

Cooling tower is used to evaporate hot brackish by direct contact with air. Exergy of moist air consist of three terms of exergy, namely thermal, chemical and mechanical exergies [13];

thermal exergy is:

$\psi_{\text {the. }}=\left(c_{\text {pa }}+\omega \cdot c_{v}\right) \cdot T_{0} \cdot\left(\frac{D B T}{D^{2} T_{o}}-1-\ln \frac{D B T}{D^{2} T_{o}}\right)$

and the chemical can te calculated by the following equation:

$$
\psi_{\text {Chem. }}=R_{\mathrm{a}} \cdot \mathrm{DBT}_{\mathrm{o}}\left[\begin{array}{c}
(1+1.68 \cdot \omega) \cdot \ln \frac{1+1.68 \cdot \omega_{0}}{1+1.68 \cdot \omega} \\
+1.68 \cdot \omega \cdot \ln \frac{\omega}{\omega_{0}}
\end{array}\right]
$$

While the mechanical exergy is:

$$
\psi_{\text {mech. }}=(1+1.68 \cdot \omega) \cdot R_{\mathrm{a}} \cdot \ln \left(\frac{\mathrm{P}}{\mathrm{P}_{\mathrm{o}}}\right)
$$

And the overall exergy of humid air is the summation of all exergies terms mentioned above.:

$\psi_{\text {air }}=\psi_{\text {the. }}+\psi_{\text {Chem. }}+\psi_{\text {mech. }}$

The objective of cooling tower in this work is to evaporate water rather than cool the water, thus, the exergy efficiency of cooling tower, in this case, equals the ratio of exergy of evaporate water to the summation of exergy differences for water and humid air across the tower.

$$
\eta_{\text {tower }}=\frac{\dot{\mathrm{m}}_{\mathrm{w}} \cdot \Psi_{8}}{\left[\dot{\mathrm{m}}_{\mathrm{w}} \cdot \Psi_{3}+\left(\dot{\mathrm{m}}_{\mathrm{w}}-\dot{\mathrm{m}}_{\text {cond }}\right) \cdot \Psi_{4}\right]+\dot{\mathrm{m}}_{\mathrm{a}} \cdot\left(\Psi_{6}-\Psi_{5}\right)}
$$

The exergy of condensate water is as follows[14]:

$$
\psi_{8}=c_{n} \cdot\left(T_{8}-T_{0}\right)-T_{0} \cdot c_{n} \cdot \ln \left(\frac{T_{8}}{T_{o}}\right)-T_{0} \cdot c_{n} \ln \left(\phi_{0}\right)
$$

\subsubsection{Heat exchanger}

The heat exchanger in this work is used to condensate water vapour from saturated air, as well as preheating brackish water before entering cooling tower. Thus the exergy efficiency of heat exchanger is:

$$
\eta_{H E x}=\frac{\dot{m}_{w} \cdot \psi_{8}+\dot{m}_{w} \cdot \Psi_{2}}{\dot{m}_{\mathrm{w}} \cdot \psi_{1}+\dot{m}_{\mathrm{a}} \cdot\left(\Psi_{7}-\psi_{5}\right)}
$$

\subsubsection{Still exergy efficiency}

The hourly exergy of solar still is the ratio of the exergy of condensate water to the absorbed solar radiation exergy rate;

$$
\eta_{\text {hour }}=\frac{\dot{m}_{w} \cdot \psi_{8}}{\Psi_{\text {solar }}}
$$

While the daily exergy efficiency of the still is the ratio of daily exergy of condensate water to the daily absorbed solar radiation exergy;

$$
\eta_{\text {daily }}=\frac{\sum \dot{m}_{\mathrm{w}} \cdot \psi_{8}}{\sum \psi_{\text {solar }}}
$$




\section{3-Results and Discussion}

Fig. 2. Shows the variation of exergy flow of water and humid air through cooling tower vs solar intensity, it can be seen from the figure that the exergy flow reduces as the solar intensity increases tell the intensity reaches about $0.45 \mathrm{~kW} / \mathrm{m}^{2}$, and then the exergy flow increases, this is due that the solar still works at non steady state during the sun rise, and after the solar reaches steady state the effect of solar intensity on exergy flow appears clearly. The effect of solar intensity on the hourly exergy efficiency of still and exergy destruction is shown in Fig. 3. It can be seen from the figure that the minimum hourly exergy efficiency is at solar intensity of about $0.45 \mathrm{~kW} / \mathrm{m}^{2}$, due to the same reason mentioned above, the figure shows that the exergy destruction is direct proportion to solar intensity. The effect of brackish water temperature entering heat exchanger versus exergy efficiency of still components is shown in Fig. 4. The figure shows that as the brackish water temperature increases the exergy efficiency increases also, but cooling tower exergy efficiency reaches maximum value at water temperature of $25^{\circ} \mathrm{C}$. The figures shows that the minimum exergy efficiencies for both cooling tower and flat plate solar collector reflects on the hourly efficiency of solar still, which is less than $1 \%$. This means that there is a huge destruction in exergy through cooling tower and solar collector. Fig. 5. Shows the effect of mass flow rate of brackish water on the solar still productivity, it can be seen from the figure there is a best value of mass flow rate of brackish water of about $0.013 \mathrm{~kg} / \mathrm{s}$ after this value the productivity reduces. Fig. 6 . shows effect of mass flow rate of brackish water on still daily efficiency and overall exergy destruction, it can be seen from the figure that the maximum daily exergy efficiency is for the mass flow rate of water of about $0.013 \mathrm{~kg} / \mathrm{s}$, while mass flow rate of water of about $0.014 \mathrm{~kg} / \mathrm{s}$ gives the maximum exergy destruction. Fig. 7. Shows the variation of still components exergy efficiency and hourly exergy efficiency versus day time, as it is expected that the maximum exergy efficiency for still and its components are at solar noon. The figure shows that the maximum exergy efficiency is for heat exchanger followed by solar collector and cooling tower.

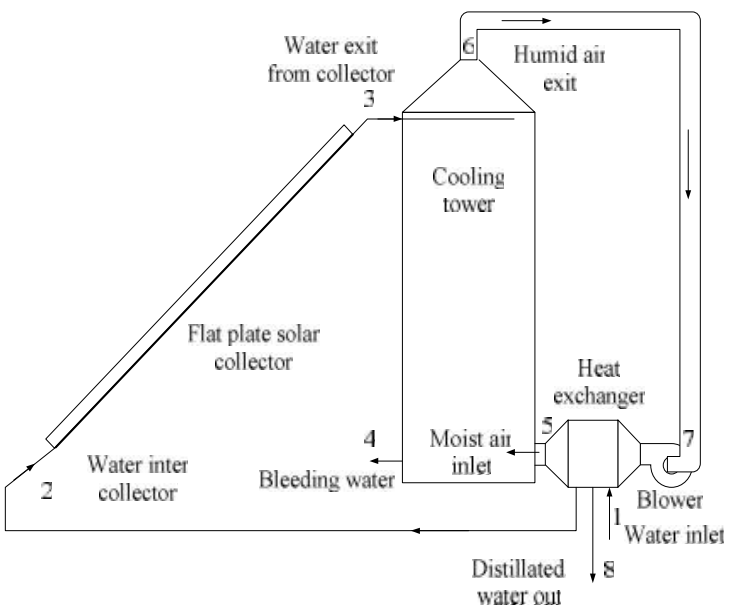

Figure 1 schematic diagram of solar still with solar collector and cooling tower

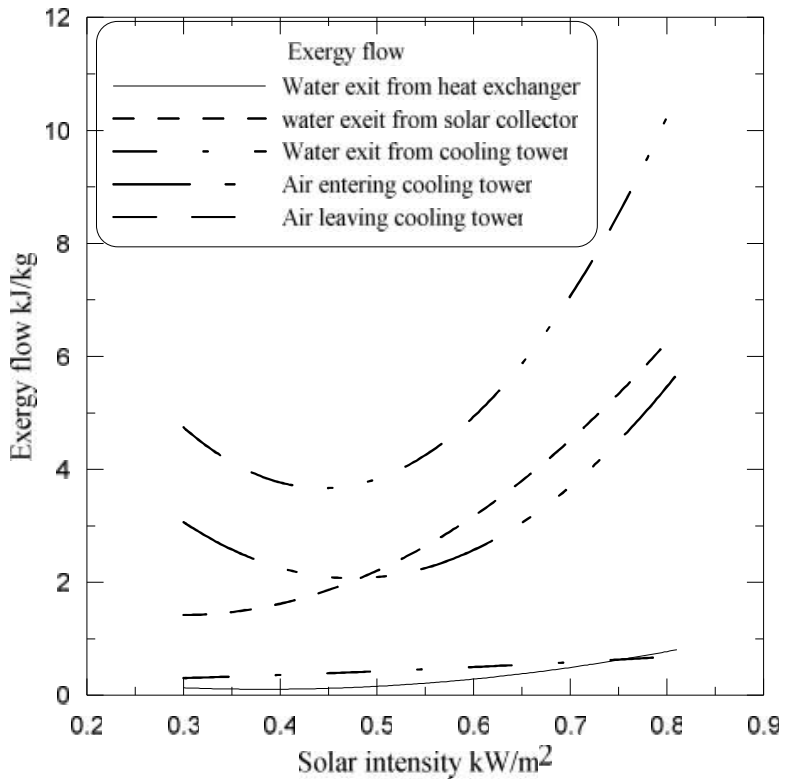

Fig. 2 The variation of moist air exergy and water exergy vs solar intensity

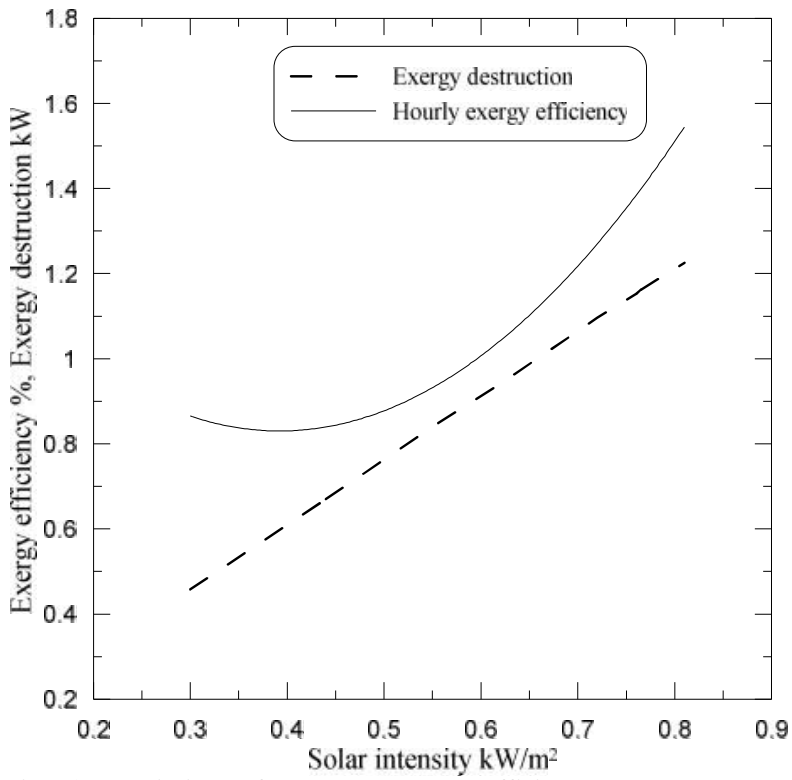

Fig. 3. Variation of Hourly exergy efficiency and exergy destruction vs solar intensity 


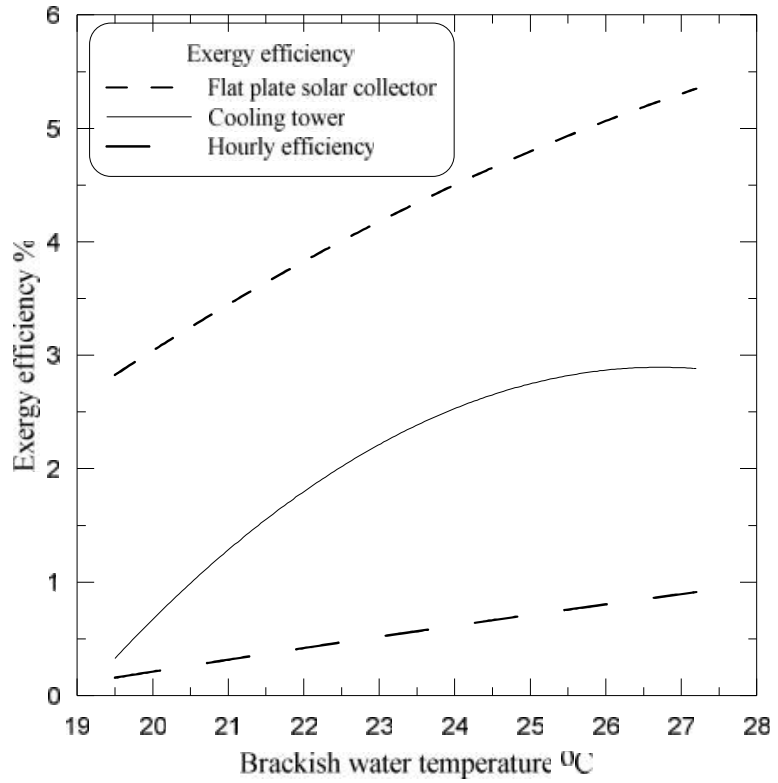

Fig. 4. Variation of exergy efficiency vs brackish water temperature

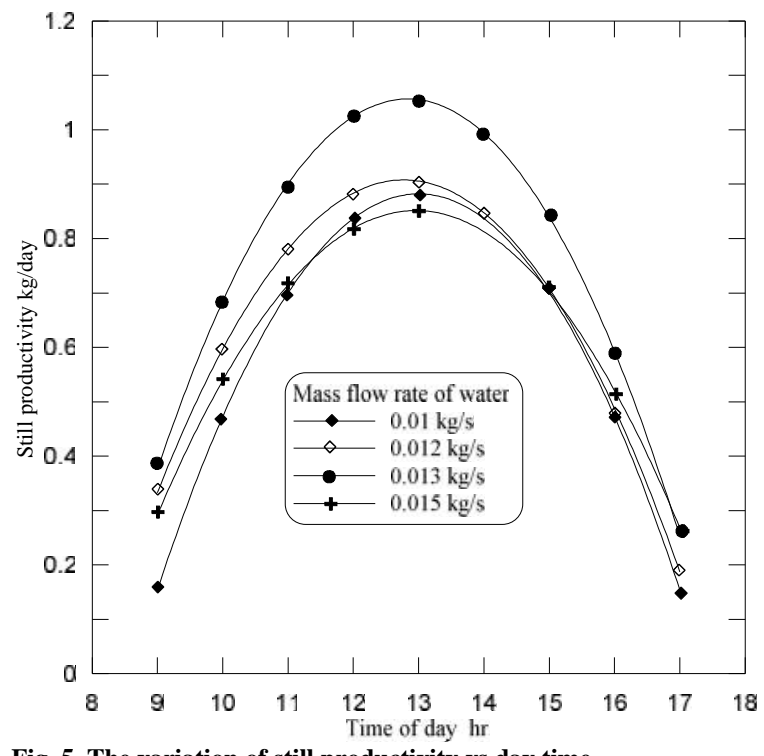

Fig. 5. The variation of still productivity vs day time

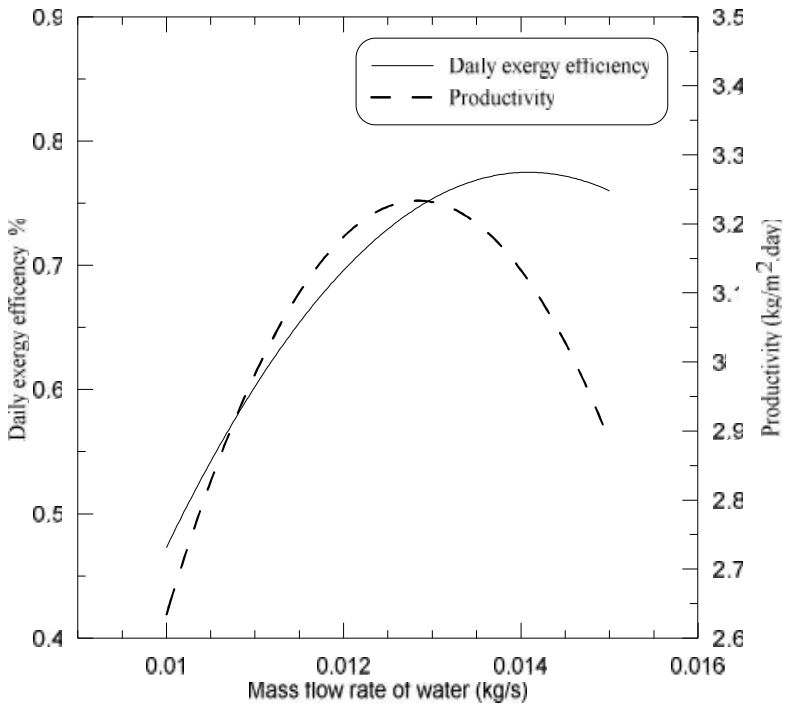

Fig. 6. The variation of daily efficency and still productivity vs day time.

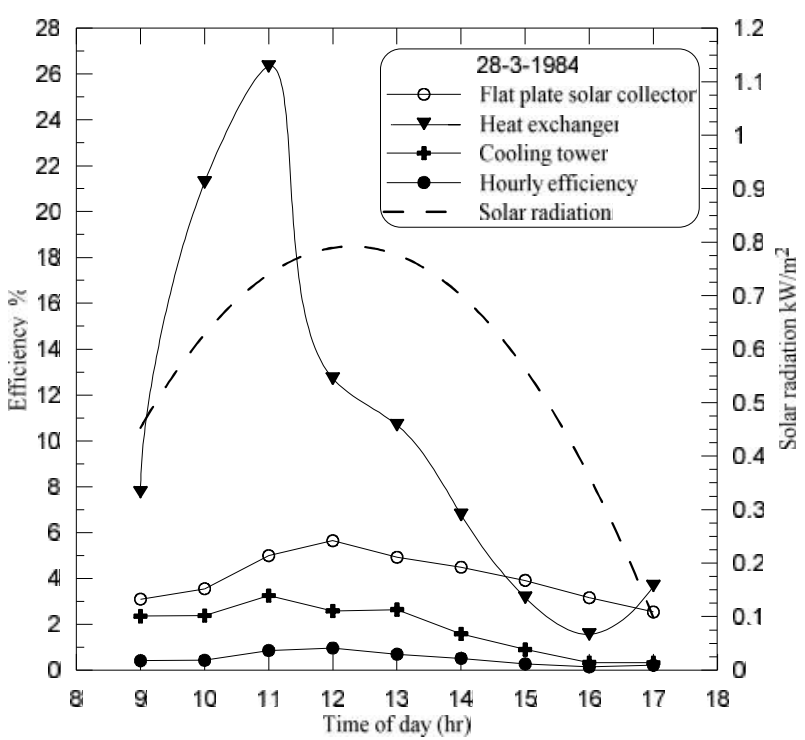

Fig.7 The variation of system components exergy vs day time 


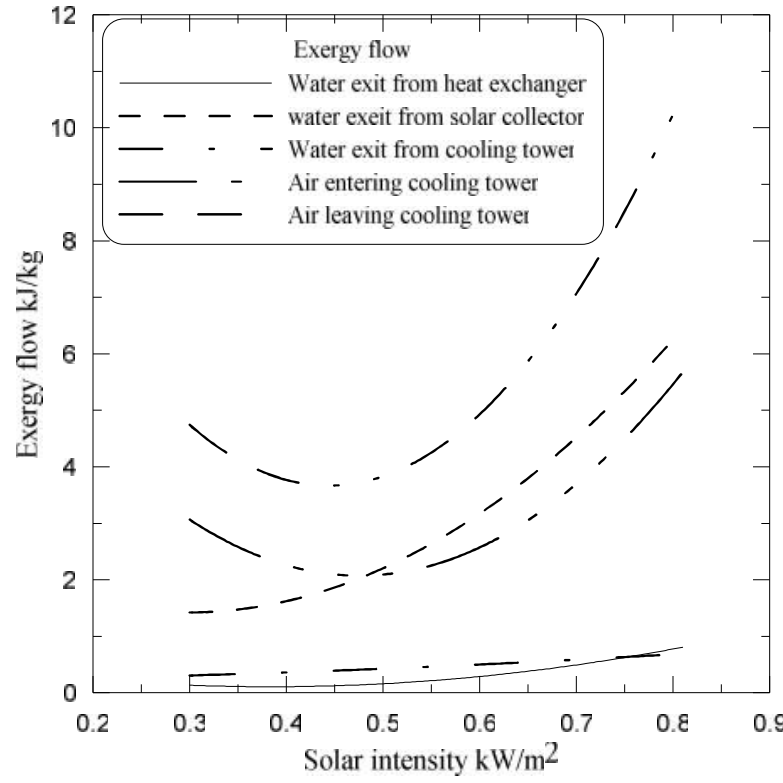

Fig. 8 The variation of moist air exergy and water exergy vs solar intensity

\section{Conclusion}

From the results obtained it can be conclude that consuming of moist air exergy through cooling tower to evaporates water only reduces the cooling tower exergy efficiency significantly, also the huge difference between ambient temperature and apparent sun temperature as exergy source reduces the solar exergy flow. The use of such combination for solar distillation gives maximum exergy efficiency of les that $1 \%$, due to huge exergy destruction in solar collector and cooling tower. The best mass flow rate of brackish water for this work is about $0.013 \mathrm{~kg} / \mathrm{s}$ which gives the maximum hourly exergy efficiency of $1.6 \%$, and daily productivity of about $3.46 \mathrm{~kg} / \mathrm{day}$.

\section{Nomenclature}

\begin{tabular}{|c|c|}
\hline A & collector area $\left(\mathrm{m}^{2}\right)$ \\
\hline $\begin{array}{l}\mathrm{C}^{\mathbf{p}} \\
\mathrm{pa}\end{array}$ & $\begin{array}{l}\text { Specific heat of air at constant pressure } \\
(\mathrm{kJ} / \mathrm{kg} \mathrm{K})\end{array}$ \\
\hline$c_{v}$ & $\begin{array}{l}\text { Specific heat of water vapour } \\
\text { constant pressure }(\mathrm{kJ} / \mathrm{kg} \mathrm{K})\end{array}$ \\
\hline$c_{n}$ & specific heat of water $(\mathrm{kJ} / \mathrm{kg} \mathrm{K})$ \\
\hline DBT & Dry bulb temperature of air $\left({ }^{\circ} \mathrm{C}, \mathrm{K}\right)$ \\
\hline $\mathrm{h}$ & Enthalpy $(\mathrm{kJ} / \mathrm{kg})$ \\
\hline I & Solar radiation intensity $\left(\mathrm{kW} / \mathrm{m}^{2}\right)$ \\
\hline$\dot{\mathrm{m}}$ & mass flow rate of brackish water $(\mathrm{kg} / \mathrm{s})$ \\
\hline $\mathrm{p}$ & Pressure ( kPa.) \\
\hline $\mathrm{R}$ & Air gas constant $(\mathrm{kJ} / \mathrm{kg} \mathrm{K})$ \\
\hline s & Entropy $(\mathrm{kJ} / \mathrm{kg} \mathrm{K})$ \\
\hline$T$ & Temperature $\left({ }^{\circ} \mathrm{C}, \mathrm{K}\right)$ \\
\hline
\end{tabular}

Greek letters

$\begin{array}{ll}\phi & \text { Relative humidity of air } \\ \omega & \text { Moisture content }\left(\mathrm{kg}_{\mathrm{w}} / \mathrm{kg}_{\mathrm{a}}\right) \\ \eta & \text { Efficiency } \\ \tau \alpha & \text { transmittance absorptance product } \\ \psi & \text { Exergy flow }(\mathrm{kJ} / \mathrm{kg}) \\ \Psi & \text { Exergy flow rate }(\mathrm{kW}) \\ \mathrm{W} & \text { Water } \\ & \\ \text { Subscripts } & \\ \mathrm{a} & \text { Air } \\ \text { Chem. } & \text { Chemical } \\ \text { coll. } & \text { Solar collector } \\ \text { cond. } & \text { Condensate } \\ \text { Hex. } & \text { Heat exchanger } \\ \text { hour. } & \text { Hourly } \\ \text { mech. } & \text { Mechanical } \\ \text { o } & \text { Dead state } \\ \text { s } & \text { Sun } \\ \text { solar } & \text { Solar } \\ \text { the. } & \text { Thermal }\end{array}$

\section{References}

[1] World Health Organization and UNICFE Joint Monitoring Program, (JMP), 2014, Progress on Drinking water and Sanitation, 2014 Update.

[2] Shahin, Mamdouh. Water resources and hydrometeorology of the Arab region. Vol. 59. Springer Science \& Business Media, 2007.

[3] Al Barwani, H. H., and Anton Purnama. "Evaluating the effect of producing desalinated seawater on hypersaline Arabian Gulf." European Journal of Scientific Research 22, no. 2 (2008): 279-285.

[4] Dimri, Vimal, Bikash Sarkar, Usha Singh, and G. N. Tiwari. "Effect of condensing cover material on yield of an active solar still: an experimental validation." Desalination 227, no. 1 (2008): 178-189.

[5] Marmouch, H., J. Orfi, and S. Ben Nasrallah. "Experimental and theoretical study on the effect cooling tower on solar desalination system." In Revue des Energies Renouvelables CICME'08 Sousse, pp. 185-192. 2008.

[6] Bhattacharyya, Amitava. "Solar stills for desalination of water in rural households." International Journal of Environment and Sustainability (IJES) 2, no. 1 (2013).

[7] Sethi, A. K., and V. K. Dwivedi. "Exergy analysis of double slope active solar still under forced circulation mode." Desalination and Water Treatment 51, no. 40-42 (2013): 7394-7400. 
[8] Ranjan, K. R., S. C. Kaushik, and N. L. Panwar. "Energy and exergy analysis of passive solar distillation systems." International Journal of LowCarbon Technologies (2013): ctt 069.

[9] Badran, Omar. "Theoretical analysis of solar distillation using active solar still."International Journal of Thermal \& Environmental Engineering 3 (2011): 113-120.

[10] Balabel, Ashraf, and Hamdy Kotbb. "Analysis of a Hybrid Renewable Energy Stand-Alone Unit for Simultaneously Producing Hydrogen and Fresh Water from Sea Water." Int. J. of Thermal \& Environmental Engineering 6, no. 2 (2013): 55-60.

[11] Ge, Zhong, Huitao Wang, Hua Wang, Songyuan Zhang, and Xin Guan. "Exergy Analysis of Flat Plate
Solar Collectors." Entropy 16, no. 5 (2014): 25492567.

[12] Bejan, A., D. W. Kearney, and F. Kreith. "Second law analysis and synthesis of solar collector systems." Journal of Solar Energy Engineering 103, no. 1 (1981): 23-28.

[13] Ren, C. Q., G. F. Tang, N. P. Li, G. F. Zhang, and J. Yang. "Analysis of exergy of moist air and energy saving potential in HVAC by evaporative cooling or energy recovery." International Journal on Architectural Science 2, no. 4 (2001): 113-117.

[14] Marletta, Luigi. "Air conditioning systems from a 2nd law perspective." Entropy12, no. 4 (2010): 859877. 